\title{
PEMILIHAN JENIS TUNGKU BIOMASSA DENGAN METODE AHP UNTUK DAERAH PEDESAAN
}

\author{
A.D.Garnadi ${ }^{1}$, D.S.Priyarsono ${ }^{2}$, M. Irzaman $^{3}$, \\ Hanni Garminia ${ }^{4}$,dan Pudji Astuti ${ }^{5}$ \\ ${ }^{1,3}$ Fakultas Matematika dan Ilmu Pengetahuan Alam \\ INSTITUT PERTANIAN BOGOR \\ Jl. Meranti, Kampus Darmaga, Bogor \\ ${ }^{2}$ Fakultas Ekonomi \& Manajemen \\ Kampus Darmaga, Bogor \\ ${ }^{4,5}$ Fakultas Matematika dan Ilmu Pengetahuan Alam \\ INSTITUT TEKNOLOGI BANDUNG \\ Jl. Ganesha No.10 Bandung
}

Pada makalah ini akan dibahas sistem pemilihan tungku biomassa dengan menggunakan metode Analytic Hierarchy Process (AHP). Sistem ini kemudian diterapkan untuk membandingkan tungku biomassa IPB dengan 2 tungku biomassa yang diedarkan oleh sebuah NGO.

Kata kunci: Analytic Hierarchy Process, Tungku Biomassa,

\section{PENDAHULUAN}

Dalam banyak fakta kehidupan, kita seringkali dihadapkan pada suatu permasalahan mulai dari yang sederhana sampai pada suatu permasalahan yang kompleks, yang tentunya membutuhkan banyak kriteria sebagai bahan pertimbangan sebelum menentukan pilihan ataupun keputusan. Adanya berbagai macam kriteria sebagai bahan pertimbangan akan meminimalisir kesalahan dan memperkuat suatu keputusan sehingga keputusan yang di ambil akan terasa lebih adil dan transparan. Salah satu kasus yang melibatkan banyak 
kriteria dan subkriteria sebagai bahan pertimbangan adalah masalah pemilihan tungku biomassa.

Pada masalah pemilihan tungku biomassa tersebut, tentu kita tidak bisa melihat satu sisi dan mengenyampingkan sisi yang lain sebagai salah satu potensi yang terintegrasi dalam kompetensi tungku biomassa. Artinya, untuk melakukan pemilihan tungku biomassa, berbagai kriteria seperti teknis dan nonteknis harus tetap diperhatikan sebagai satu kesatuan kompetensi. Salah satu metode yang bisa mengakomodir berbagai kriteria penilaian yang ada adalah Analytic Hierarchy Process (AHP). AHP bermanfaat untuk menghadapi perspektif rasional dan irrasional, serta resiko dan ketidakpastian dalam lingkungan yang kompleks. Disamping itu juga, AHP sangat fleksibel untuk digunakan dalam pengambilan keputusan yang melibatkan perbandingan elemen keputusan yang sulit untuk dinilai secara kuantitatif.

Pada prinsipnya, metode AHP ini memecah-mecah suatu situasi yang kompleks, tidak terstruktur, ke dalam bagian-bagian secara lebih terstruktur, yaitu dengan membentuk struktur hirarki dari suatu permasalahan yang ingin diteliti. Hal ini berdasarkan asumsi bahwa reaksi natural manusia ketika menghadapi pengambilan keputusan yang kompleks adalah mengelompokkan elemenelemen keputusan tersebut menurut karakteristiknya secara umum.

Pada makalah ini penulis akan memanfaatkan metode AHP untuk membangun sistem pemilihan tungku biomassa. Untuk itu, lebih dulu akan diulas metode Analytic Hierarchy Process (AHP) yang diperkenalkan oleh Saaty di sekitar tahun 1970an sebelum diperkenalkan sistem pemilihan tungku biomassa menggunakan metode AHP. Selanjutnya sistem ini diimplementasikan untuk menentukan tungku biomassa untuk memenuhi kebutuhan energi rumah tangga yang memiliki sumber energi biomassa di Indonesia, terutama di pedesaan.

\section{ANALYTIC HIERARCHY PROCESS(AHP)}

Dalam suatu proses pengambilan keputusan, adanya berbagai macam kriteria, ketidakpastian atau ketidaksempurnaan informasi merupakan suatu kendala yang harus disikapi dengan bijak. Salah satu solusi yang memungkinkan untuk mengatasai berbagai macam kendala itu adalah Analytic Hierarchy Process (AHP). 
AHP dikembangkan oleh Thomas L. Saaty di Wharton School of Business University of Pennsylvania pada sekitar tahun 1970an dan baru dipublikasikan pada tahun 1980 dalam bukunya yang berjudul Analytic Hierarchy Process. Seiring dengan perkembangan zaman, AHP tidak saja digunakan untuk menentukan prioritas pilihan-pilihan dengan banyak kriteria, tetapi penerapannya telah meluas sebagai model alternatif untuk menyelesaikan bermacammacam masalah; seperti memilih portofolio, analisis manfaat biaya, peramalan dan lain sebagainya. Dengan kata lain, AHP menawarkan penyelesaian masalah keputusan yang melibatkan seluruh sumber kerumitan. Hal ini dimungkinkan karena AHP cukup mengandalkan pada intuisi yang datang dari pengambil keputusan yang cukup akan informasi dan memahami masalah keputusan yang dihadapi sebagai input utamanya.

Dari struktur yang kompleks, tidak terstruktur, kemudian dibentuk struktur hirarki. Dalam hirarki sendiri terdapat goal atau tujuan utama yang hendak dicapai, kriteria-kriteria, sub-kriteria, dan alternatif-alternatif. Dari sini, pembuat keputusan kemudian membuat perbandingan berpasangan untuk memperoleh prioritas seluruh alternatif yang ada. Hasil dari perbandingan berpasangan ini akan membentuk matrik dimana skala rasio diturunkan dalam bentuk vektor eigen.

Secara umum terdapat tiga prinsip yang menjadi satu kesatuan di dalam mengkonstruksi AHP. Tiga prinsip yang dimaksud adalah: decomposition, comparative judgment, dan synthesis of priority.

\section{Decomposition}

Setelah persoalan didefenisikan, maka perlu dilakukan decomposition yaitu memecah persoalan yang utuh menjadi unsur-unsur yang lebih sederhana. Selanjutnya, dibuat struktur hirarki yang diawali dengan tujuan umum, dilanjutkan dengan kriteria-kriteria, kemudian sub-kriteria dengan kemungkinan alternatif-alternatif pada tingkatan kriteria yang paling bawah. Jika ingin mendapatkan hasil yang akurat, pemecahan juga dilakukakan terhadap unsur-unsur sampai tidak mungkin dilakukan pemecahan lagi. Pemecahan tersebut akan menghasilkan beberapa tingkatan dari suatu persolan. Oleh karena itu proses analisis ini dinamakan hierarkhi.

\section{Comporative Judgment}


Prinsip ini berarti membuat penilaian tentang kepentingan relatif dua elemen pada suatu tingkat tertentu dalam kaitannya dengan tingkat diatasnya. Penilaian ini merupakan inti dari AHP karena ia akan berpengaruh terhadap prioritas elemen-elemen. Hasil dan penilaian ini akan tampak lebih baik bila disajikan dalam bentuk matriks perbandingan berpasangan ( pairwise comparison).

Misalkan kita mempunyai $n$ obyek yang akan dibandingkan dari suatu tingkat hirarki yang dinotasikan oleh $C_{1}, C_{2}, C_{3}, \ldots, C_{n}$ dengan bobot pengaruh masing-masing $w_{1}, w_{2}, \ldots, w_{n}$. Bila diketahui nilai perbandingan elemen $C_{i}$ terhadap elemen $C_{j}$ adalah $a_{i j}$ $, i, j=1,2,3, \ldots, n$, maka kita dapat menuliskan matriks pairwise comparison dari $A$ sebagai berikut:

$$
A \cong \begin{array}{c|cccc} 
& C_{1} & C_{2} & \cdots & C_{n} \\
\hline C_{1} & a_{11} & a_{12} & \cdots & a_{1 n} \\
C_{2} & a_{21} & a_{22} & \cdots & a_{2 n} \\
\vdots & \vdots & \vdots & \ddots & \vdots \\
C_{n} & a_{n 1} & a_{n 2} & \cdots & a_{33}
\end{array}
$$

Matriks $A$ merupakan matriks positif $n \times n$ yang reciprocal sehingga $a_{j i}=\frac{1}{a_{i j}}$. Matriks tersebut konsisten jika $a_{i j} . a_{j k}=a_{i k}$, untuk $i, j, k$ $=1,2,3, \ldots, n$. Dengan demikian $a_{i j}=\frac{a_{i k}}{a_{j k}}[5]$. Jika $A$ konsisten dan $a_{i j}=\frac{w_{i}}{w_{j}}$, dengan $i, j=1,2,3, \ldots, n$ maka dengan mengalikan $A$ dengan vektor $w$ diperoleh $A w=n w$. Ini menujukan bahwa $w$ merupakan eigenvektor dari matriks $A$ dengan nilai eigen $n$.

Skala dasar yang digunakan untuk membandingkan elemenelemen tersebut oleh Saaty [4], dibuat dalam bentuk skala perbandingan yang selanjutnya kita sajikan sebagai berikut;

Tabel 1. Skala Perbandingan Berpasangan 


\begin{tabular}{|c|c|}
\hline Bobot & Definisi \\
\hline 1 & Sama pentingnya \\
\hline 3 & Agak lebih penting yang satu dengan yang lainnya \\
\hline 5 & Cukup penting yang satu dengan yang lainnya \\
\hline 7 & Sangat penting yang satu dengan yang lainnya \\
\hline 9 & Mutlak lebih penting yang satu dengan yang lainnya \\
\hline $2,4,6,8$ & Nilai antara \\
\hline Kebalikan & $\begin{array}{c}\text { Jika } i \text { mempunyai nilai lebih tinggi dari } j, \\
\text { maka }\end{array}$ \\
& $j$ bernilai kebalikannya bila dibanding dengan $i$ \\
\hline Rasio & Rasio yang didapat langsung dari pengukuran \\
\hline
\end{tabular}

\section{Synthesis of Priority}

Dari setiap matriks pairwise comparison yang telah dibuat kemudian dicari vektor eigennya untuk mendapatkan prioritas local (local priority). Karena matriks pairwise comparison terdapat pada setiap tingkat, maka untuk mendapatkan global priority harus dilakukan sintesa di antara local priority. Prosedur melakukan sintesa ini berbeda menurut bentuk hirarki. Pengurutan elemen-elemen menurut kepentingan relatif melalui prosedur sintesa dinamakan priority setting. Dari prioritas global akhir itulah yang digunakan sebagai dasar pengambilan keputusan.

Disamping ketiga prinsip dasar tersebut, hal lain yang harus diperhatikan dalam membuat suatu keputusan dengan AHP adalah konsistensi dari jawaban. Idealnya, setiap orang menginginkan keputusan yang konsisten. Namun demikian banyak kasus yang kita tidak dapat mengambil keputusan yang perfectly consistent.

Dalam menggunakan AHP ada beberapa faktor yang dapat menyebabkan responden memberikan jawaban yang tidak konsisten, yaitu: keterbatasan informasi, kurang konsentrasi, ketidakkonsistenan dalam dunia nyata, struktur model yang kurang memadai. Sebagai contoh ketika seseorang mengatakan madu dua kali lebih manis dari pada gula, dan gula tiga kali lebih manis dari pada sirup, maka kita tidak bisa memaksakan bahwa madu enam kali lebih manis dari pada sirup. Salah satu hal yang perlu dicatat dalam hal inkonsistensi adalah bahwa tujuan utama proses pengambilan keputusan bukanlah derajat inkonsistensi yang rendah. Inkonsistensi rasio yang rendah bersifat perlu namun belum cukup untuk 
sebuah keputusan yang baik. Dibandingkan konsistensi, kita lebih baik mengutamakan akurasi. [3]

Untuk mengatasi hal tersebut, maka Saaty telah mendefinisikan kekonsistenan suatu keputusan yang dikenal dengan Indek konsistensi (CI) sebagai berikut,

$$
C I=\frac{\lambda_{\max }-n}{n-1}
$$

Adapun batas ketidakkonsistenan suatu matrik, oleh Saaty diukur dengan menggunakan Consistency Ratio (CR) yaitu perbandingan antara indek konsistensi (CI) dengan nilai Random Indeces (RI)

$$
C R=\frac{C I}{R I}
$$

Random Indek tersebut bergantung pada ukuran suatu matrik. Jika nilai consistency ratio (CR) yang diperoleh kurang dari 10 persen, maka keputusan yang diambil dianggap konsisten, akan tetapi jika rasio konsistensi yang diperoleh ternyata lebih dari 10 persen, maka si pembuat keputusan disarankan melakukan kajian ulang terhadap matrik perbandingan yang diperoleh. Ini artinya keputusan yang diambil kurang konsisten.

Tabel 2. Tabel Random Indices (RI)

\begin{tabular}{|l||c|c|c|c|c|c|c|c|c|c|c|}
\hline $\mathrm{N}$ & 1 & 2 & 3 & 4 & 5 & 6 & 7 & 8 & 9 & 10 & 11 \\
\hline $\mathrm{RI}$ & 0 & 0 & 0.58 & 0.90 & 1.12 & 1.24 & 1.32 & 1.41 & 1.45 & 1.49 & 1.51 \\
\hline
\end{tabular}

Adapun tahapan- tahapan proses pengambilan keputusan dengan AHP adalah sebagai berikut: [4]

1. Mendefinisikan masalah dan menentukan solusi yang diinginkan.

2. Membuat struktur hirarki yang diawali dengan tujuan umum, dilanjutkan dengan sub tujuan-sub tujuan, kriteria dan kemungkinan alternative pada tingkatan kriteria yang paling bawah. 
3. Membuat matrik perbandingan berpasangan (pairwise comparison) yang menggambarkan kontribusi relatif atau pengaruh setiap elemen terhadap masing-masing tujuan atau kriteria yang setingkat di atasnya.

4. Melakukan perbandingan berpasangan sehingga diperoleh ketetapan (judgment) seluruhnya sebanyak $n \times[(n-1) / 2]$ buah [5].

5. Menghitung prioritas dan menguji kekonsistenannya.

6. Mengulangi langkah 3, 4, dan 5 untuk seluruh tingkat hirarki.

\section{PENERAPAN AHP DALAM PEMILIHAN TUNGKU BIOMASSA}

Pada bagian ini akan dibahas penggunaan AHP dalam menentukan tungku biomassa. Pemilihan tungku biomassa ini kita lakukan untuk memenuhi kebutuhan energi rumah tangga yang memiliki sumber energi biomassa di Indonesia, terutama di pedesaan. Untuk menghindari subyektifitas dalam pengambilan data pembobotan antar kriteria / subkriteria, maka penilaian antar obyek penelitian dilakukan oleh lebih dari satu orang. Masing-masing tujuan, kriteria, subkriteria sampai pada alternatif pemilihan dapat kita sajikan dalam bentuk hirarki sebagai berikut

Garis-garis yang menghubungkan kotak-kotak antar level merupakan hubungan yang diukur dengan perbandingan berpasangan dengan arah ke level yang lebih tinggi [1]. Tujuan dari penelitian ini adalah untuk menentukan tungku biomassa. Kriteria dan subkriteria yang menjadi pertimbangan di dalam menentukan tungku biomassa disajikan hanya pada level 2 .

Proses perhitungannya telah dilakukan secara berjenjang dengan setiap matriks perbandingan berpasangan pada setiap tingkat hierarkhi, sesuai dengan langkah-langkah penggunaan AHP di atas. Pada tabel 3 disajikan skala prioritas hasil perhitungan antar kriteria dan sub kriteria tersebut. Dari hasil perhitungan didapatkan prioritas antara empat kriteria yang dibandingkan yaitu KA1, KA2, KA3 dan KA4 masing-masing sebesar x1, x2, x3, dan x4. Sedangkan dari lima sub-kriteria K2 yang terdiri atas A21 dan A22 diperoleh prioritas berturutan y1 dan y2. Dengan demikian prioritas 


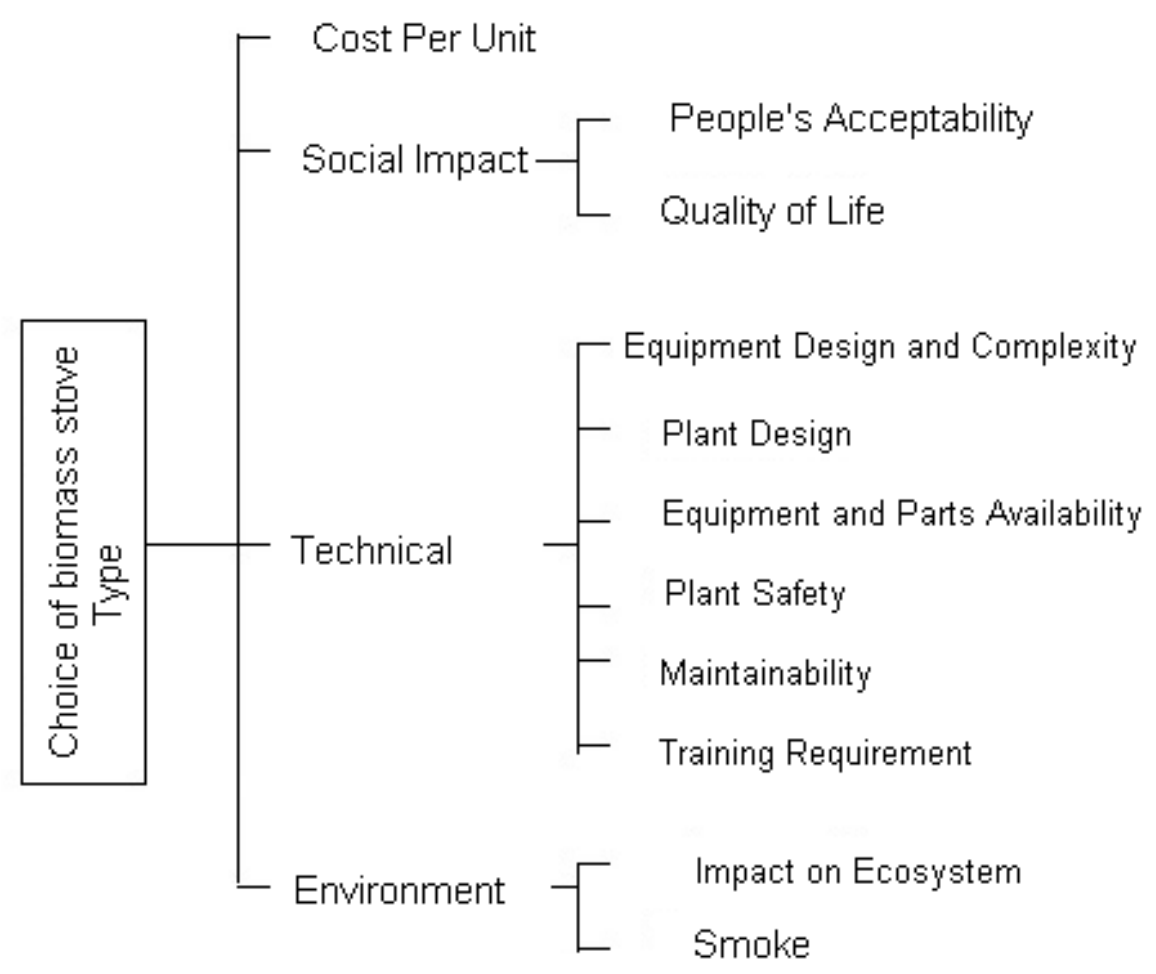

Figure 1: Hierarkhi penilaian pemilihan tungku biomassa 
tertinggi dari kriteria adalah A? dan prioritas tertinggi dari subkriteria bidang teknis sendiri adalah Axy.

Adapun pada bidang KA3 yang terdiri atas 6 sub-kriteria, didapatkan prioritas sebagai berikut; untuk A3i diperoleh prioritas secara berturutan yi, $1_{i j} i 6$. Berdasarkan prioritas yang diperoleh, maka A3z mendapatkan prioritas yang lebih dibandingkan dengan subkriteria yang lain.

Adapun pada bidang KA4 yang terdiri atas 2 sub-kriteria, didapatkan prioritas sebagai berikut; untuk A4i diperoleh prioritas secara berturutan yi, 1,2. Berdasarkan prioritas yang diperoleh, maka A4z mendapatkan prioritas yang lebih dibandingkan dengan subkriteria A4y.

\section{Tabel 3.}

\section{Hasil Perhitungan Prioritas antar Kriteria dan Subkriteria}

\begin{tabular}{|c|c|c|c|c|c|c|c|c|}
\hline Kriteria & Subkriteria & Prior & $C R$ & Prior & $C R$ & Prior & $C R$ & Prior \\
\hline A1. Cost Per Unit & & & & & & & & 0,602 \\
\hline A2. Social Impact & A21. People Acceptability & & & & & & & \\
\hline & A22. Quality of Life & & & & & & & \\
\hline A3. Technical & A31. Equipment Design amd Complexity & & & & & & & \\
\hline & A32. Plant Design & & & & & & & \\
\hline & A33. Equipment and Parts Availability & & & & & & & \\
\hline & A34. Plant Safety & & & & & & & \\
\hline & A35. Maintainability & & & & & & & \\
\hline & A36. Training Requirement & & & & & & & \\
\hline A4 Environment & A41 Impact on Ecosystem & & & & & & & \\
\hline
\end{tabular}

Pada tabel 4 disajikan hasil akhir prioritas global dari masingmasing calon tungku biomassa yang berpasangan dengan masingmasing kriteria dan subkriteria. Pada tabel tersebut diperoleh gambaran mengenai prioritas dari keseluruhan kriteria dan subkriteria sebagai dasar penilaian tungku biomassa yang dikenakan pada masing-masing kandidat. Dalam menentukan prioritas calon diawali dengan membuat matriks pairwise comparison pada setiap sub kriteria pada level paling bawah. Pada penelitian ini ada XX matriks pairwise comparison pada alternatif. Banyaknya kandidat yang dimaksud ada sebanyak delapan orang yang diperoleh dari 3 jenis tungku yang berbeda yang terdiri dari tungku A, tungku $\mathrm{B}$, dan tungku C. Untuk mempermudah di dalam menganalisis masing-masing tungku, maka pada tabel disajikan dalam bentuk simbol yang mempresentasikan asal dari tiap jenis tungku.

\section{Tabel 4. Tabel Prioritas Global dari Setiap Alternatif.}




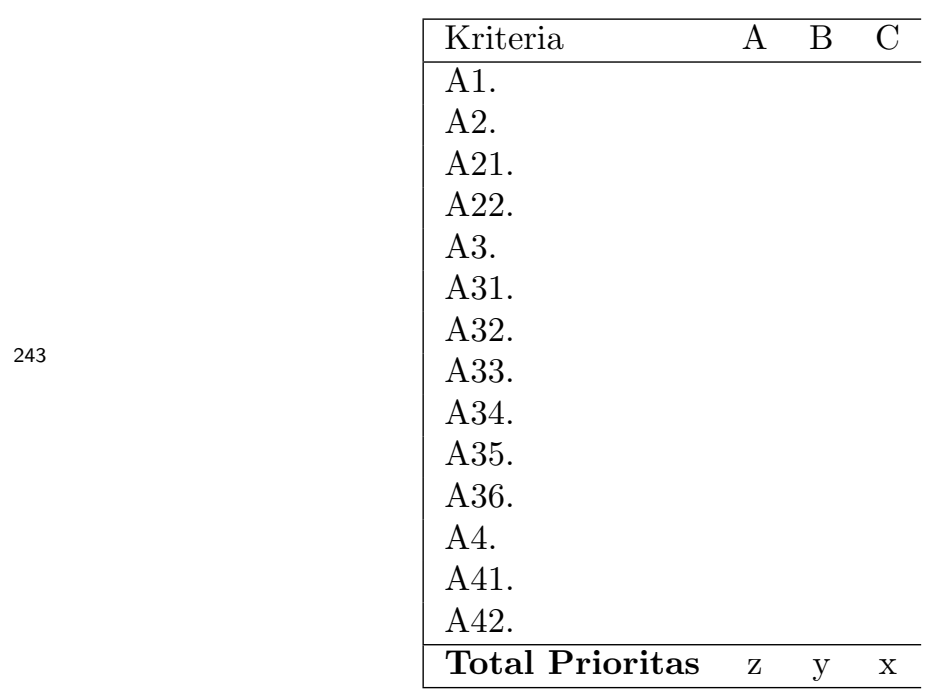

\section{Keterangan:}

Pilihan tungku biomassa:
A. Tungku A
B. Tungku B
C. Tungku C

Dengan memperhatikan tabel di atas diperoleh urutan total prioritas yang pada akhirnya akan digunakan sebagai dasar pengambilan keputusan dalam pemilihan tungku biomassa . Berdasarkan hasil perhitungan yang sudah ada, maka diperoleh kandidat peringkat pertama, kedua, ketiga, dan seterusnya dengan perincian sebagai berikut: kandidat peringkat pertama adalah tungku X dengan nilai global prioritas sebesar 0 , xxx, yang kedua adalah tungku Y dengan total prioritas global 0,yyy. Sedangkan prioritas terkecil adalah $\mathrm{Z}$ dengan skor 0 ,zzz.

\section{KESIMPULAN}

Dari pembahasan yang sudah diuraikan di atas , dapat kita simpulkan bahwa telah dapat dipilih suatu sistem pengambilan keputusan dengan menggunakan metode AHP untuk menentukan prioritas calon tungku biomassa untuk memenuhi kebutuhan energi rumah tangga yang memiliki sumber energi biomassa di Indonesia, terutama di pedesaan. AHP dapat memberikan solusi yang opti- 
265

${ }_{266}$ References

${ }_{267}^{26}$ [1] Analytic Hierarchy Process - Wikipedia, the free en268 269

mal dengan cara yang transparan. cyclopedia, http://en.wikipedia.org/wiki/AHP (didownload 11 Nopember 2008)

[2] Masood A Badri;Mohammed H Abdulla., Awards of excellence in institution: an AHP approach, International Journal of Educational Management V.18 No. 4 (2004) pp224-242.

[3] Penelitian dan Pengembangan Ekonomi UGM (PPEFE UGM),2006,"Modul Pelatihan", Disrict and Provincial Economic Development Training.

[4] Saaty, T.L., Decision making for leaders, University of Pittsburg, (1988).

[5] Saaty, T.L., Decision-making with the AHP: Why is principal eigenvector necessary, EJOR 145 (2002) 85-91. 